e-ISSN: 2549-9122

\title{
Optimalisasi Pengelolaan Sampah dalam Perspektif Pendidikan Islam Di Perumahan Kelurahan Tamansari Kecamatan Bondowoso
}

\author{
Oleh: \\ * Iro Waziroh \\ Email: Irowaziroh6@gmail.com \\ Universitas Bondowoso, Indonesia
}

\begin{abstract}
Abstrak
Waste is one of the problems that can not be avoided by the population. Increasing population causes increased activity of the population, which means also can increase the amount of waste, it is due to the many sources of waste that have sprung up such as in housing, tourist attractions, and other public facilities, which can cause increased waste in housing tamansari village bondowoso district, a waste management system that is available is still limited and they rely on empty land disposal of waste and TPS there is still not good and the condition lug garbage in housing tamansari village bondowoso district still mixed or without sorting, so that people who throw their garbage has not been able to do the sorting for a variety of organic and inorganic waste. So in the housing tamansari village bondowoso district requires efforts to optimize the process of waste management in the review based on the generation and waste characteristics and land conditions, So these problems to do an analysis condition of waste management in housing tamansari village bondowoso district, then get the facilities and infrastructure needs is not good enough, so it appears the problem of garbage in the location is still a lack of research and polling services lug garbage in each source. Based conditions, people still follow the custom of throwing garbage in the river and dispose of their garbage in vacant land. Thus the need in optimizing waste management in housing tamansari village bondowoso district, with the addition of lug and waste collection system in accordance with the state of the location, so that the lug and garbage collection system to be effective. And sticking ti the qur'an and hadis about cleanliness is part of faith.
\end{abstract}

Keywords: Garbage Character, Optimization, Islamic Education Perspective 



\section{Pendahuluan}

Meningkatnya jumlah penduduk secara signifikan serta adanya perubahan pola konsumsi masyarakat secara tidak langsung menambah jenis, dan karakteristik sampah, bahkan semakin beragam. Permasalahan sampah yang timbul hakikatnya juga menjadi permasalahan nasional, yang perlu di lakukan penanganan secara komprehensif dan terpadu. Sampah menurut undang-undang pengelolaan sampah no 18 tahun 2008 yaitu berupa sisa kegiatan sehari-hari manusia dan/atau proses alam yang berbentuk padat. ${ }^{1}$

Sampah merupakan bahan bahan buangan yang dihasilkan dari kegiatan manusia, segala macam organisme yang ada di alam ini selalu menghasilkan limbah (sampah) atau bahan buangan. Sebagian besar limbah yang dihasilkan oleh organisme yang ada di alam ini bersifat organik, kecuali limbah yang berasal dari aktivitas manusia yang dapat bersifat organik maupun anorganik. Bentuk dan macam limbah yang dihasilkan manusia tergantung pada beradaban manusia.

Wilayah Global sudah dalam tingkat berbahaya seperti yang di ungkapkan oleh Laman Nature dan dikutip dalam berita harian yaitu media online mongabay, mereka mempublikasikan riset terbaru oleh Tamara S. Galloway, Mathew Cole, dan Ceri Lewis dari Universitas Exeter, Inggris pada April 2017 lalu. Riset itu berjudul Interactions of microplastic debris throughout the marine ecosystem. Dalam artikelnya,

\footnotetext{
${ }^{1}$ Undang-Undang Republik Indonesia Nomor 18 Tahun 2008 Tentang Pengelolaan Sampah, http://www.menlh.go.id/DATA/UU18-2008. pdf, diakses pada 22/05/17 pukul 13:01
}

para peneliti menyatakan bahwa jumlah produksi plastik Global saat ini mencapai 300 juta ton per tahun. Sekitar 50 persen dari plastik tersebut hanya digunakan sekali sebelum dibuang, menghasilkan jumlah plastik yang dibakar. Dari jumlah tersebut, ada sekitar 4,8 hingga 12,7 juta ton plastik dibuang ke laut pada 2014 . $^{2}$

Permasalahan mengenai timbulan, komposisi, dan karakteristik sampah merupakan hal yang sangat menunjang dalam menyusun sistem optimalisasi pengelolaan persampahan di suatu wilayah khususnya di daerah perumahan. Permasalahan tersebut harus tersedia agar dapat disusun suatu alternatif sistem pengelolaan sampah yang baik. Jumlah timbulan sampah ini biasanya akan berhubungan dengan elemen-elemen pengelolaan sampah antara lain, pemilihan peralatan, misalnya wadah, alat pengumpulan, dan pengangkutan, perencanaan rute pengangkutan, fasilitas untuk daur ulang, dan luas dan jenis TPA. (Tri Padmi 2005).

Latuconsina dan rusdi (2017:1) menjelaskan kelestarian alam adalah hal utama yang harus diperhatikan umat manusian dan merupakan bagian dari umat islam dalam bentuk rasa syukur, untuk memenuhi kebutuhan hidup umat manusia, Allah menciptakan alam semesta beserta lingkungannya sudah selayaknnya umat manusia menjaga kelestarian alam dengan mau menjaga kebersihan, merawatnya serta tidak merusak dan membuat kotor lingkungan yang dapat berakibat merugikan kehidupan manusia itu sendiri, seperti sabda rasulullah yang artinya " dari malik al-asy'ari dai berkata Rasulullah SAW bersabda kebersihan adalah

\footnotetext{
2 http://www.mongabay.co.id /2017/05/15/ paus-sperma-itu-pun-mati-karenasampahplastik/ diakses pada 22/05/2017 pukul 12:49.
} 
separuh dari iman (HR. muslim) . Serta Allah juga berfirman didalam alqur'an surah. Ash-Syu'ara : 42:30. yang artinya " dan apa saja musibah yang menimpa kamu, maka adalah di sebabkan oleh perbuatan tangan mu sendiri dan Allah memanfaatkan sebagian besar dari kesalahan kesalahanmu " QS. Ash-Syu'ara : 42:30. ${ }^{3}$

Dari firman Allah dan sabda rasulullah di atas sudah menjadi kewajiban kita untuk menjaga kelestarian alam ini dengan baik yang tentunya tidak membuang sampah sembarangan serta menjaga lingkungan agar terciptanya lingkungan yang bersih dan sehat. Hal ini harus di mulai dengan pemberian contoh pendidikan yang baik kepada anak-anak kita serta masyarakat disekitar kita untuk selalu mengajarkan dan mengingatkan agar membuang sampah pada tempatnya.

Allah SWT menciptakan

lingkungan sebagai bagian dari kehidupan manusia yang dapat dimanfaatkan dan dijaga kelestariannya. Lingkungan hidup manusia mencakup segala macam sumber daya alam yang ada di sekitar manusia. Lingkungan hidup merupakan kesatuan ruang dengan semua benda, daya, keadaan, dan mahluk hidup termasuk manusia dan perilakunya yang mempengaruhi kelangsungan kehidupan dan kesejahteraan manusia serta mahluk hidup lainnya. ${ }^{4}$

\footnotetext{
3 R.Andi Ahmad gunadi;ansharullah "pengetahuan pengelolaan sampah sebagai sumber belajar pendidikan karaktersiswa SD menurut perspektif islam" fak. Ilmu pend. UM Jakarta 2019 https://jurnal.umj.ac.id/index.php/MaA16/ind $\underline{\underline{e x}}$

4 Atikel Muhammad Nur "Faktor-Faktor Penentu Tingkat Partisipasi Masyarakat dan Perspektif Islam Tentang Pengelolaan
}

Dari Permasalahan tersebut, sampah di perumahan kelurahan tamansari Kecamatan bondowoso menjadi prioritas utama. Hal ini disebabkan karena banyaknya sumber-sumber sampah dari rumah tangga yang berasal dari kegiatan sehari-hari atau kawasan komersial, seperti fasilitas sosial, fasilitas umum dan fasilitas lainnya yang dapat menyebabkan sampah bertambah. Dari pemasalahan ini, diharapkan khususnya di perumahan kelurahan tamansari Kecamatan bondowoso memerlukan upaya sistematis, yang meliputi pengurangan dan penanganan sampah dari sistem pengelolaan sampah yang di tinjau berdasarkan karakteristik sampah, dan Timbulan Sampah dalam perspektif pendidikan islam. Oleh karena itu perlu dilakukannya pendekatan yang lebih baik agar dapat meningkatkan partisipasi masyarakat, sehingga dengan kesadaran sendiri masyarakat dapat menjaga kebersihan lingkungannya. Karena itu, pengelolaan sampah sangat tergantung pada kerjasama dan kesadaran setiap masyarakat, Dalam penelitian ini peneliti berfokus pada optimalisasi dalam pengelolaan sampah dalam perspektif pendidikan islam di perumahan kelurahan tamansari Kecamatan bondowoso, dengan pendekatan penelitian menggunakan metode kualitatif

\section{Kajian Konseptual}

Sampah adalah bahan buangan dalam bentuk padat atau semi padat yang dihasilkan dari aktifitas manusia atau hewan yang dibuang karena tidak diinginkan atau digunakan lagi (Tchobanoglous dkk,1993). Berdasarkan UU RI Nomor 18 Tahun

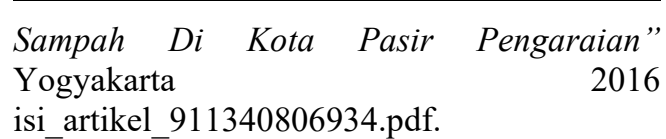


2008 dan PP RI Nomor 81 Tahun 2012, sampah adalah sisa kegiatan sehari-hari manusia dan/atau proses alam yg berbentuk padat. ${ }^{5}$ Timbulan sampah adalah banyaknya sampah yang timbul dari masyarakat dalam satuan maupun berat perkapita perhari, atau perluas bangunan, atau perpanjang jalan (SNI 19-2454-2002). Pengelolaan limbah atau sampah ini memiliki keterkaitan dengan pengelolaan lingkungan (environmental management), pengelolaan lingkungan dapat dilakukan bila telah dilakukan kajian secara menyeluruh. Pengelolaan lingkungan harus dilakukan dengan mengintegrasikan antara lingkungan fisik alami, manusia, dan sistem sosialnya. Perkembangan pemikiran ini mengandung konsekwensi bahwa pemahaman lingkungan tidak hanya sebatas lingkungan fisik akan tetapi juga aspek sosial ekonomi budaya serta memadukan pemikiran konsep "ABC" untuk menjelaskan tiga komponen lingkungan yang tidak terpisahkan yaitu Abiotik (A), Biotik (B), Culture (C). ${ }^{6}$

$$
\text { Pengelolaan }
$$

sampah

diselenggarakan untuk mengurangi dan menanggulangi dampak pencemaran lingkungan yang diakibatkan oleh kemajuan industri dan meningkatnya jumlah penduduk. Selain hal tersebut tujuan diselenggarakannya adalah untuk mencapai kesejahteraan yang

\footnotetext{
${ }^{5}$ Undang-Undang Republik Indonesia Nomor 18 Tahun 2008 Tentang Pengelolaan Sampah, http://www.menlh.go.id/DATA/UU18-2008. pdf, diakses pada 22/05/17 pukul 13:01

${ }^{6}$ Mursid Raharjo, Memahami Amdal Jilid 2, (Yogyakarta: Graha Ilmu, 2014), hlm. 22.
}

sesungguhnya dan beriringan dengan majunya industri. ${ }^{7}$

Penerapan aspek manajemen dalam pengelolaan limbah, khususnya sampah perkotaan dapat dilakukan melalui pendekatan manajemen yakni perencanaan, pengorganisasian, pengendalian dan evaluasi, pemanfaatan fungsi manajemen dalam pengelolaan sampah perkotaan ini akan lebih efektif bila dilakukan mulai dari perencanaan, pengorganisasian dan pengawasan, berikut adalah beberepa fungsinya. ${ }^{8}$

Fungsi perencanaan dalam manajemen meliputi serangkaian keputusan-keputusan termasuk penentuan - penentuan tujuan, kebijakan, membuat program, menentukan metode dan prosedur serta menciptakan jadwal waktu pelaksanaan. Dalam implementasinya fungsi perencanaan dibutuhkan dalam pengelolaan sampah perkotaan, dengan menentukan tujuan "bersih itu adalah sehat".

Pengelolaan sampah dengan paradigma baru tersebut dilakukan dengan kegiatan pengurangan dan penanganan sampah. Pengurangan sampah meliputi kegiatan pembatasan, penggunaan kembali, dan pendauran ulang, sedangkan kegiatan penanganan sampah meliputi pemilahan, pengumpulan, pengangkutan, pengolahan, dan pemrosesan akhir ${ }^{9}$

Menurut UU-18/2008 tentang Pengelolaan Sampah, terdapat 2 kelompok utama pengelolaan sampah, yaitu Pengurangan sampah (waste

\footnotetext{
7 Wisnu Arya Wardhana, Dampak Pencemaran Lingkungan, hlm 160

${ }^{8}$ Mursid Raharjo, Memahami Amdal Jilid 2, hlm. 22

${ }^{9}$ Undang-Undang Republik Indonesia Nomor 18 Tahun 2008 Tentang Pengelolaan Sampah, hlm. 30
} 
minimization), yang terdiri dari pembatasan terjadinya sampah R1), guna-ulang (R2) dan daur ulang (R3), Penanganan sampah (waste handling), yang terdiri dari, Pemilahan dalam bentuk pengelompokan dan pemisahan sampah sesuai dengan jenis, dan/atau sifat sampah. Pengumpulan dalam bentuk pengambilan dan pemindahan sampah dari sumber sampah ke tempat penampungan sementara (TPS) atau tempat pengolahan sampah terpadu. Pengangkutan dalam bentuk membawa sampah dari sumber dan/atau dari tempat penampungan sampah sementara atau dari tempat pengolahan sampah terpadu menuju ke tempat pemrosesan akhir (TPA). Pengolahan dalam bentuk mengubah karakteristik, komposisi sampah. Pemrosesan akhir sampah dalam bentuk pengembalian sampah dan/atau residu hasil pengolahan sebelumnya ke media lingkungan secara aman. (Enri Damanhuri 2006).

Teknik operasional pengelolaan sampah Permukiman meliputi dasardasar perencanaan untuk kegiatan:

$\begin{array}{ll}\checkmark & \text { Pewadahan sampah } \\ \checkmark & \text { Pengumpulan sampah } \\ \checkmark & \text { Pemindahan sampah } \\ \checkmark & \text { Pengangkutan sampah } \\ \checkmark & \text { Pengelolaan dan pendaur-ulangan } \\ & \text { sampah } \\ \checkmark & \text { Pembuangan akhir sampah }\end{array}$
Bagan alir Teknik Operasional pengelolaan sampah diperlihatkan pada Gambar 1.1. di bawah ini:

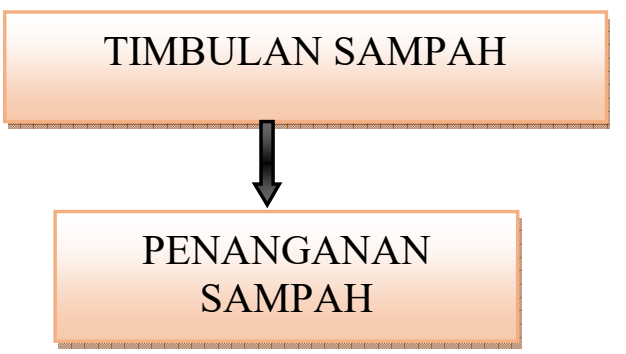

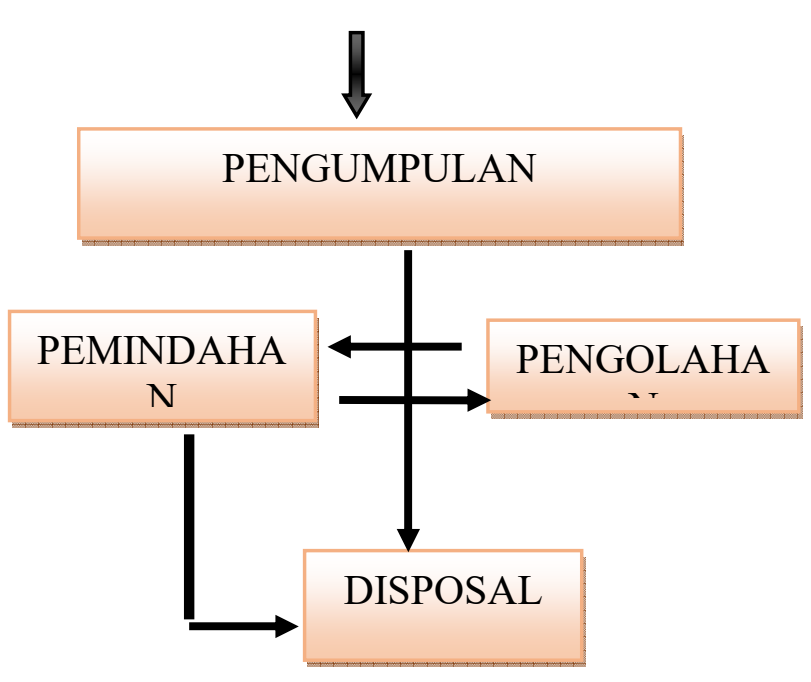

1. Pewadahan Sampah

Kegiatan pewadahan sampah merupakan kegiatan penyimpanan sampah sementara yang dilakukan sendiri oleh masyarakat atau pemilik rumah, sebelum sampah dikumpulkan ditempat penampungan sementara atau diangkut ketempat pembuangan akhir. Jenis wadah yang digunakan antara lain: kantong plastik, keranjang plastik, tong sampah, bak sampah, kontainer.

2. Pengumpulan Sampah

Kegiatan pengumpulan sampah merupakan kegiatan operasional yang dimulai dari sumber sampah ketempat penampungan sementara (TPS)/trasfer depo, sebelum diangkut ketempat pembuangan akhir (TPA).

Peralatan yang diperlukan dalam pengumpulan sampah terdiri dari:

- Kantong plastik

- Kontainer

- Transfer depo

3. Pengangkutan

Kegiatan pengangkutan sampah merupakan kegiatan operasional yang dimulai dari titik-titik pengumpulan 


\begin{tabular}{|c|c|}
\hline sampah/TPS/Transfer & Depo \\
\hline sampai ke & Untuk \\
\hline $\begin{array}{l}\text { menunjang kelancaran } \\
\text { pengangkutan sampah dipe }\end{array}$ & $\begin{array}{l}\text { dalam } \\
\text { erlukan }\end{array}$ \\
\hline $\begin{array}{l}\text { armada angkut seperti } \\
\text { Dump. }\end{array}$ & \\
\hline
\end{tabular}

4. Pengolahan

Pengolahan sampah terdiri dari:

a. Pengolahan sampah organik

- Komposting

Merupakan pengolahan sampah organik atau sampah basah secara biologis melalui proses penguraian yang berlangsung dalam kondisi aerobik maupun anerobik

- Pembuatan gas bio

Merupakan gas-gas yang dapat dimanfaatkan sebagai bahan bakar, yang dihasilkan dari proses pembusukan sampah organik (berupa kotoran manusia, kotoran hewan, dan sampah pertanian) secara anaerobik.

b. Pengolahan sampah anorganik Misalnya melalui proses pembakaran/insenerasi. ${ }^{10}$

Ditinjau dari perspektif pendidikan islam adalah islam mengajari dan menjungjung tinggi hidup bersih dan sehat. Tidak hanya sekedar keindahan dan manfaat kesehatan, terdapat beberapa keutamaan menjaga kebersihan yang bisa muslimin dapatkan Dalam

10 SKRIPSI Taufiqurrahman "Optimalisasi Pengelolaan Sampah Berdasarkan Timbulan Dan Karakteristik Sampah Di Kec. Pujon Kabupaten Malang" Jurusan Teknik Lingkungan Fakultas Teknik Sipil 2016.
Islam, kebersihan merupakan sebagian dari Iman. Karena dasar inilah, setiap Muslimin diwajibkan untuk selalu menjaga kebersihan, baik kebersihan diri sendiri maupun lingkungan. Oleh karena itu kita selaku manusia seyogyanya harus saling mengingatkan antra satu dengan yang lainnya untuk tidak membuangan sampah sembarangan, hal ini merpakan pendidikan islam yang di ajarkan oleh rasulullah kepada umatnya untuk menjaga kebersihan karena bersih sebagian dari iman ${ }^{11}$

Dalam Pendidikan islam, islam adalah agama yang menjunjung tinggi hidup bersih, karenanya Islam juga mengajarkan pada pemeluknya untuk menjaga kebersihan. Ajaran tentang menjaga kebersihan itu di antaranya berdasarkan hadits berikut:

Pertama الإيمان من النظافة "Kebersihan itu bagian dari iman,"

dan kedua hadits: الإيمان شطر الطهور "Kesucian itu bagian dari iman".

Meski cukup populer, hadits yang pertama menurut para ahli hadits riwayatnya dinilai dhoif atau lemah, sedangkan hadits yang kedua riwayatnya shohih atau kuat. Dari sisi makna antara an-Nazhofah dan athThuhur, yang sepintas sama, tetapi memiliki arti yang berbeda. Kata anNazhofah artinya bersih hanya meliputi zhohir atau yang nampak saja. Sedangkan at-Thuhur artinya suci, yaitu bersih baik secara zhohir maupun bathin atau yang tidak Nampak. $^{12}$

\footnotetext{
11 Khasaanah Islam umma https://umma.id/post/4-keutamaanmenjaga-kebersihan-dalam-islam913453?lang=fid

12 Artikel Zaenal muttaqin" islam ajarkan menjaga kebersihan-mina news https://minanews.net/islam-ajarkanpentingnya-menjaga-kebersihan-olehzaenal-muttaqin
} 
Masalah kebersihan merupakan masalah pokok dalam ajaran Islam dan ini juga banyak ditunjukkan oleh para ulama fiqih terdahulu. Mereka biasanya dalam menyusun kitab-kitab fiqih selalu manjadikan bab bersuci atau Thoharoh ditempatkan di bab pertama. Seperti kitab-kitab fiqih yang disusun oleh ulama empat madzhab.

Di dalam Al Quran banyak ayat yang menyinggung masalah kebersihan, diantaranya pada ayat 108 Surat AtTaubah, Allah SWT berfirman:

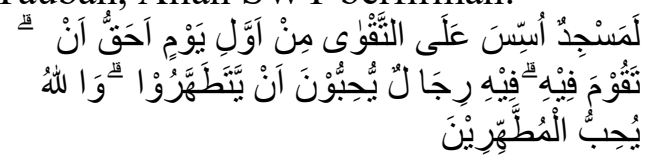

“...... Sungguh, masjid yang didirikan atas dasar takwa sejak hari pertama adalah lebih pantas engkau melaksanakan sholat di dalamnya. Di dalamnya ada orang-orang yang ingin membersihkan diri. Allah menyukai orang-orang yang bersih." (QS. At-Taubah 9: Ayat 108) ${ }^{13}$

Sudah sangat jelas pendidikan islam mengajarkan kita untuk selalu berprilaku bersih dan sehat sebagaimana firman Allah dan sabda rasulullah diatas, dalam melaksanakan perintah tersebut tentu kita tidak membuang sampah sembarangan, kita sebagai mahluk ciptaan Allah yang dilengkapi akal dan pikiran kita tahu langkah apa yang harus kita ambil dalam mengoptimalisasi pengelolaan sampah khususnya yang ada di perumahan kelurahan tamansari kecamatan bondowoso.

\section{Metode}

Dalam penelitian ini penulis menggunakan jenis penelitian kualitatif, yaitu penelitian yang bermaksud untuk memahami

${ }^{13}$ Al-Quran Surah At-Taubah 9: Ayat 108 fenomena tentang apa yang dialami oleh subjek penelitian misalnya adalah perilaku, persepsi, motivasi, tindakan, interview dan lain sebagainya, secara holistik, dan dengan cara deskripsi dalam bentuk kata-kata dan bahasa, pada suatu konteks khusus yang alamiah dan dengan memanfaatkan berbagai metode ilmiah. Dilakukan deskriptif kualitatif yaitu suatu penelitian yang bertujuan untuk menerangkan fenomena sosial atau peristiwa. ${ }^{14}$

Teknik Pengumpulan Data. yang digunakan oleh penulis dalam penelitian ini adalah:

\section{1) Observasi}

Pengamatan terlibat adalah pengamatan yang dilakukan sambil sedikit banyak berperanserta dalam kehidupan orang yang kita teliti, adapula strategi lapangan yang secara simultan memadukan analisis dokumen, wawancara dengan responden dan informan, partisipasi dan observasi langsung dan interopeksi. Hal yang sudah diobservasi adalah tentang proses manajemen dalam pengelolaan sampah dan proses berjalannya pengelolaan tersebut dari awal berdirinya Bank Sampah dan adanya pengelolaan bio kompos.

2) Wawancara

Wawancara adalah bentuk komunikasi antara dua orang, melibatkan seseorang yang ingin memperoleh informasi dari seseorang lainnya dengan mengajukan pertanyaanpertanyaan, berdasarkan tujuan

14 Lexy J.Moleong, Metodelogi Penelitian Kualitatif, (Bandung: PT. Remaja Rosdakarya, 2013), hlm. 6. 
tertentu. Jenis wawancara yang sudah digunakan adalah pembicaraan informal yaitu pertanyaan yang diajukan bergantung pada pewawancara itu sendiri, jadi bergantung pada spontanitasnya dalam mengajukan pertanyaan kepada terwawancara. Wawancara yang akan dilaksanakan adalah seputar tentang proses berjalannya pengelolaan sampah dan proses awal tentang cara menggerakan ataupun cara pembentukan mindset masyarakat yang awalnya tidak mempedulikan sampah dan lingkungannya dan yang akan di wawancarai adalah ketua RT setempat, pengurus pengelola sampah, dan masyarakat.

3) Dokumentasi

Dokumentasi merupakan catatan peristiwa yang sudah berlalu. Dokumen bisa berbentuk tulisan, gambar, atau karyakarya monumental dari seseorang. Dokumen yang berbentuk tulisan misalnya catatan harian, sejarah kehidupan (life histories), cerita, biografi, peraturan, kebijakan,. Dokumen yang berbentuk gambar misalnya foto, gambar hidup, sketsa, dan lainnya. Dokumen yang berbentuk karya misalnya karya seni, yang berupa gambar, patung, film dan lain-lain. Dokumen yang akan diambil dalam penelitian ini adalah berupa dokumen berbentuk tulisan dari beberapa yang sudah didapatkan seperti hasil wawancara, file-file tentang keadaan geografis dan kependudukan, sejarah tentang berdirinya pegelolaan sampah di kampung tersebut dan lain sebagainya.

4) Analisis Data

Analisis data adalah tahapan yang penting dalam menyelesaikan suatu kegiatan penelitian, untuk memberikan arti makna, dan nilai yang terkandung didalam data. Tujuan dari adanya analisis data adalah untuk meringkas data dalam bentuk yang mudah diapahami dan mudah untuk didefinisikan, sehingga hubungan antara masalah penelitian dapat dipelajari dan dapat diuji. Penulis Samaji Sarosa mengutip salah satu pendapat yang diutarakan oleh Milea and Huberman pada tahun 1984 yaitu bahwa aktivitas dalam analisis data kualitataif dilakukan secara interaktif dan berlanngsung secara terus Reduksi data Semakin lama peneliti ke lapangan, maka jumlah data akan semakin banyak, kompleks dan rumit. Untuk itu harus dilakukan reduksi data. Reduksi data adalah merangkum, memilih hal-hal yang pokok, memfokuskan pada hal-hal yang penting, mencari tema dan polanya, dengan demikian kesimpulan-kesimpulan finalnya dapat ditarik dan diverifikasi. Penyajian data Langkah berikutnya setelah proses mereduksi data adalah penyajian data. Penyajian data adalah sekumpulan informasi tersusun yang memberi kemungkinan adanya penarikan kesimpulan dan pengambilan tidakan. Mencermati penyajian data peneliti akan lebih mudah 
memahami dan mengerti hal yang harus dilakukannya.

\section{Pembahasan}

Perkembangan dan pertambahan jumlah sampah tidak dapat dibendung lagi. Setiap manusia bertambah, maka secara otomatis, jumlah sumber sampah pun bertambah, baik yang sifatnya sampah rumah tangga, komersil, ataupun industri. Klasifikasi Sumber Sampah menurut sumbernya ada dua yaitu dari domestik dan non domestik antara lain:

$\checkmark$ Daerah Perumahan

Yaitu (rumah tangga) Sampah di suatu pemukiman biasanya dihasilkan oleh satu atau beberapa keluarga yang tinggal dalam suatu bangunan atau asrama yang terdapat di desa atau di kota. Jenis sampah yang dihasilkan biasanya sisa makanan dan bahan sisa proses pengolahan makanan atau sampah basah (garbage), sampah kering (rubbsih), perabotan rumah tangga tidak layak pakai, abu atau sisa tumbuhan kebun. Sumber sampah yang terdapat di daerah perumahan dibagi menjadi beberapa bagian, yaitu:

- Perumahan masyarakat berpenghasilan tinggi (Permanen), memiliki ciri dinding bangunannya dari tembok, berlantai semen atau keramik, dan atapnya berbahan genteng.

- Perumahan masyarakat berpenghasilan menengah (Semi Permanen), memiliki ciri dindingnya setengah tembok dan setengah bambu, atapnya terbuat dari genteng maupun seng atau asbes, banyak dijumpai pada ganggang kecil.

- Perumahan masyarakat berpenghasilan rendah/daerah kumuh (Non Permanen), ciri rumahnya berdinding kayu, bambu atau gedek, dan berlantai semen, atap rumahnya dari seng maupun asbes. Sedangkan sumber sampah dari non domestik antara lain :

$\checkmark$ Daerah Komersial

Yaitu umumnya didominasi oleh kawasan perniagaan, hiburan dan lain-lain. Yang termasuk kategori daerah komersial di antaranya adalah pasar, pertokoan, industri dan lainlain.

$\checkmark \quad$ Fasilitas Umum

Yaitu merupakan sarana/prasarana perkotaan yang dipergunakan untuk kepentingan umum. Yang termasuk dalam kategori fasilitas umum ini adalah perkantoran, sekolah, rumah sakit, apotik, gedung olah raga, taman, jalan, saluran/sungai dan lain-lain.

$\checkmark$ Fasilitas Sosial

Yaitu merupakan sarana prasarana perkotaan yang digunakan untuk kepentingan sosial atau bersifat sosial. Fasilitas sosial ini meliputi panti-panti sosial (rumah jompo, panti asuhan) dan tempat-tempat ibadah (masjid, gereja, dan lainlain).

$\checkmark \quad$ Sumber Lain

Yaitu sumber dari klasifikasi sumber-sumber sampah tersebut, dapat dikembangkan lagi jenis sumber-sumber sampah yang lain sesuai dengan 
kondisi kotanya atau peruntukan tata guna lahannya.

Berdasarkan pengamatan yang dilakukan oleh peneliti dalam pengoptimalisasi pengelolaan sampah dalam perspektif islam diperumahan kelurahan tamansari kecamatan bondowoso, selama ini terlihat bahwa masyarakat masih belum mempunyai budaya yang baik dalam masalah sampah, terbukti dengan belum adanya kesadaran penuh akan pentingnya kebersihan dan pengelolaan sampah yang baik. Sehingga sejauh ini peran serta masyarakat dalam pengelolaan sampah masih kurang. Seperti kebiasaan masyarakat disana membuang sampah dilahan kosong dan adapula yang membuang sampah ke selokan air atau sungai.

Maka dari inilah masyarakat masih kurang sadar dengan sistem pengelolaan sampah yang ada akan tetapi hal itu sebagian kecil dari mereka karena sebagian besar dari mereka sudah banyak menyadari akan pentingnya kebersihan sehingga ada yang sebagian dari masyarakat yang mempunyai lahan belakang rumah yaitu membakar sampah plastik atau sampah kering di belakang rumah mereka yang jauh dari perumahan warga, dan ada juga yang membuangnya ke TPS dan ada juga yang menggunakan jasa petugas untuk di jemput kerumahnya masing-masing dengan kondisi sampah telah dibungkus plastik.

Proses menjalankan optimalisai pengelolaan sampah yang dilaksanakan adalah dengan menggunakan metode intervensi komunitas yaitu dengan cara melibatkan masyarakat perumahan kelurahan tamansari kecamatan bondowoso secara langsung, baik dalam hal perencanaan, pelaksanaan kegiatan hingga saat mengevaluasi program. Tujuan dilibatkannya masyarakat tersebut adalah agar mereka mampu menghadapi permasalahan sampah dengan mandiri dan mampu mengajarkannya kepada generasi penerusnya, serta dapat meningkatkan kehidupan sosial mereka dalam berpartisipasi untuk masyarakat dan menjaga ligkungan. Peningkatan partisipasi masyarakat bukan hanya di kalangan masyarakat saja, melainkan di dunia pendidikan yang ada disekitarnya, seperti dimushollah, pondok pesantren dan sekolah-sekolah, faslitias umum dan lainnya. Selain proses pelaksanaan pengelolaan tersebut, berikut cara-cara yang mereka lakukan dalam pengoptimalisasi pengelolaan sampah dalam perspektif islam yaitu dengan cara mengelola sampah anorganik yang telah dipilah untuk disetorkan ke bank sampah yang dibuka satu bulan satu kali di setiap masing-masing RW, sedangkan untuk sampah organik mereka mengolahnya menjadi pupuk kompos cair organik yang nantinya akan mereka komersilkan ke ranah yang lebih luas dan harapan mereka agar pupuk kompos cair tersebut dapat menjadi ikon untuk warga masyarakat Bumi. Sistem pewadahan pada kelurahan Tamansari kecamatan bondowoso masih tercampur antara sampah basah ( sampah organik) dan sampah kering ( sampah anorganik ). Dimana sampah yang diperoleh dari sumber sampah masih tercampur.

Adapun berbagai kapasitas yang dapat membantu mengurangi jumlah penumpukan sampah di perumahan kelurahan tamansari kecamatan bondowoso seperti adanya penyediaan kotak sampah di lokasi tertentu sebagai wadah sampah, dari kondisi lapangan sistem pewadahan 
masih tercampur dan wadah sampah yang masih umum digunakan oleh masyarakat setempat adalah wadah sampah plastik wadah sampah tong sampah. Berbagai fasilitas pengangkut dan pengumpul sampah seperti gerobak, kendaraan roda tiga, container dan truk pengangkut sampah juga telah disediakan akan tetapi sedikit tidak memadai. hal ini adalah salah satu alat penunjang kebutuhan dalam proses penanganan sampah diperumahan kelurahan Tamansari kecamatan bondowoso.

Sedangkan dalam proses pengumpulan sampah dilakukan oleh petugas kebersihan dengan cara pengambilan langsung dari rumah ke rumah dan ada pula yang mengantarkan sendiri sampahnya ke TPS. dimana pengumpulan sampah ini menggunakan alat pengumpul berupa truk damp yang kemudian sampah dibawah ke TPA. (lahan ditaman krocok). Sampah yang sudah dibawa ke lokasi TPA, oleh petugas TPA dilakukan pemisahan antara sampah organik dan anorganik, seperti sampah anorganik dipisahkan dan kemudian dipilah berdasarkan jenisnya yaitu sampah gardus, sampah plastik dan sampah botol. Walaupun sampah tersebut sudah dipilah berdasarkan jenisnya masih sangat banyak sampah yang tidak diatasi sebagaimana semestinya sehingga menimbulkan penumpukan sampah di Lokasi TPA Taman krocok. Dimana terlihat bahwa banyak sampah di TPA Taman krocok yang dibuang di jurang tanpa dilakukan pengolahan, dan sampah tersebut juga seringkali dibakar.

Jadi secara umum dalam pengoptimalisasi pengelolaan sampah dalam perspektif islam diperumahan kelurahan tamansari kecamatan bondowoso terdiri dari kegiatan pewadahan sampah, pengumpulan sampah, pembakaran sampah, pengangkutan sampah di TPS menggunakan truk damp menuju TPA yang ada di taman krocok untuk dikelolah dan di bakar

\section{Kesimpulan}

Proses menjalankan pelaksanaan pengelolaan sampah yang dilaksanakan adalah dengan menggunakan metode intervensi komunitas yaitu dengan cara melibatkan masyarakat secara langsung, baik dalam hal perencanaan, pelaksanaan kegiatan hingga saat mengevaluasi program. Tujuan dilibatkannya masyarakat adalah agar mereka mampu menghadapi permasalahan sampah dengan mandiri dan mampu mengajarkannya kepada generasi penerusnya, serta dapat meningkatkan kehidupan sosial mereka. Kehidupan sosial mereka dalam berpartisipasi untuk masyarakat dan menjaga ligkungan. Karena hal tersebut sebagian dari perintah Allah dan rosulnya untuk menjaga kebersihan.

Berdasarkan hasil penelitian dalam mengoptimalisasi pengelolaan sampah dalam perspektif pendidikan islam diperumahan kelurahan tamansari kecamatan bondowoso, maka di dapatkan mengenai kebutuhan sarana dan prasarana masih kurang, dan dapat dilihat dari sumber sampah yang dihasilkan oleh masyarakat diperumahan kelurahan tamansari kecamatan bondowoso dapat di daur ulang untuk mengurangi timbulan sampah. Optimalisasi Pengelolaan Sampah pendidikan islam diperumahan kelurahan tamansari kecamatan bondowoso Berdasarkan timbulan, karakteristik dan peran serta masyarakat yaitu:
1. Pengelolaan
sampah
diperumahan
kelurahan 
tamansari

kecamatan

bondowoso perlu dengan

adanya penambahan pewadahan,

sehingga dapat mengurangi timbulan sampah yang dibuang ke badan sungai tempat sembarangan.

2. Perlu dilakukan ke depannya merencanakan pembangunan Tempat Pembuangan sampah Sementara yang lebih memadai, agar dapat mengurangi penumpukan sampah dan meminimalisir bau tidak sedap di sekitar lokasi yang kebetulan dipinggir jalan raya.

3. Dengan minimnya keterbatasan transportasi pengangkut sampah seperti gerobak, kendaraan roda tiga, perlu dilakukan penambahan sehingga mempermudah mengangkut sampah pada kawasan permukiman atau di dalam perumahan. Dan perkantoran.

4. Perlu adanya keterlibatan antara masyarakat dengan pihak pengelola kebersihan untuk memelihara dan menjaga lingkungan daerah sekitar tempat mereka tinggal, agar tidak membuang sampahnya ke badan sungai. Serta membuangan sampah sembarangan.

5. Mengajak masyarakat untuk mengolah sampah di sumber seperti sampah organik dan anorganik untuk mengurangi timbulan sampah dan dapat dijadikan kerajinan yang bernilai tinggi, dan membuat kompos dan lain sebagainya.

6. Perlu Saling mengingatkan akan pentingnya kebersihan karena hal tersebut sebagian dari iman yang seyogyanya selaku umat islam mematuhi atas perintahNYA.

\section{Daftar Pustaka}

Hosaini, H. (2020). Pembelajaran dalam era "new normal" di pondok pesantren Nurul Qarnain Jember tahun 2020. LISAN AL-HAL: Jurnal Pengembangan Pemikiran dan Kebudayaan, 14(2), 361-380.

Samsudi, W., \& Hosaini, H. (2020). Kebijakan Sekolah dalam Mengaplikasikan Pembelajaran Berbasis Digital di Era Industri 4.0. Edukais: Jurnal Pemikiran Keislaman, 4(2), 120-125.

Mahtum, R., \& Zikra, A. (2022, November). Realizing Harmony between Religious People through Strengthening Moderation Values in Strengthening Community Resilience After the Covid 19 Pandemic. In The 4th International Conference on University Community Engagement (ICON-UCE 2022) (Vol. 4, pp. 293299).

Hosaini, H., \& Samsudi, W. (2020). Menakar Moderatisme antar Umat Beragama di Desa Wisata Kebangsaan. Edukais: Jurnal Pemikiran Keislaman, 4(1), 110.

Hosaini, H. (2020). Integrasi Konsep Keislaman Yang Rahmatan Lil 'Alamin Menangkal Faham Ekstremisme Sebagai Ideologi Beragama Dalam Bingkai Aktifitas Kegiatan Keagmaan Mahasiswa Di Kampus Universitas Bondowoso. Edukais: Jurnal Pemikiran Keislaman, 3(1), 12-30.

Hosaini, H., \& Kurniawan, S. (2019). Manajemen Pesantren dalam Pembinaan Umat. Edukais: Jurnal Pemikiran Keislaman, 3(2), 82-98.

Muis, A., Eriyanto, E., \& Readi, A. (2022). Role of the Islamic Education teacher in 
the Moral Improvement of Learners. At-Tarbiyat: Jurnal Pendidikan Islam, 5(3).

Halim, A., Hosaini, H., Zukin, A., \& Mahtum, R. (2022). PARADIGMA ISLAM MODERAT DI INDONESIA DALAM MEMBENTUK PERDAMAIAN DUNIA. JISMA: Jurnal IImu Sosial, Manajemen, dan Akuntansi, 1(4), 705-708.

Zukin, A., \& Firdaus, M. (2022). Development Of Islamic Religious Education Books With Contextual Teaching And Learning. At-Tarbiyat: Jurnal Pendidikan Islam, 5(1).

Hosaini, H., Zikra, A., \& Muslimin, M. (2022). EFFORTS TO IMPROVE TEACHER'S PROFESSIONALISM IN THE TEACHING LEARNING PROCESS. AlRisalah: Jurnal Studi Agama dan Pemikiran Islam, 13(2), 265-294.

Salikin, H., Alfani, F. R., \& Sayfullah, H. (2021). Traditional Madurese Engagement Amids the Social Change of the Kangean Society. RETORIKA: Jurnal IImu Bahasa, 7(1), 32-42.

Hosaini, H., \& Fikro, M. I. (2021). PANCASILA SEBAGAI WUJUD ISLAM RAHMATAN LI AL-ALAMIIN. Moderation/ Journal of Islamic Studies Review, 1(1), 9198.

Hosaini, H. (2020). Ngaji Sosmed Tangkal Pemahaman Radikal melalui Pendampingan Komunitas Lansia dengan sajian Program Ngabari di Desa Sukorejo Sukowono Jember. As-Sidanah: Jurnal Pengabdian Masyarakat, 2(1), 159190.

Agustin, Y. D., Hosaini, H., \& Agustin, L. (2021). ANALYSIS OF THE IMPACT OF EARLY MARRIAGE ON ADOLESCENT REPRODUCTIVE HEALTH BASED ON HEALTH PERSPECTIVES AND ISLAMIC RELIGION. UNEJ e-Proceeding, 103107.
Hosaini, H., \& Kamiluddin, M. (2021). Efektivitas Model Pembelajaran Means-Ends Analysis (MEA) dalam meningkatkan Keterampilan Komunikasi Interpersonal dan Pemecahan Masalah pada mata pelajaran Fikih. Edukais: Jurnal Pemikiran Keislaman, 5(1), 43-53.

'Amir, Najib Khalid al-, Tarbiyah Rasulullah, terj. Ibnu Muhammad dan Fakhruddin Nursyam, cet. ke-4, Jakarta: Gema Insani Press, 2000.

Hosaini, H. (2020). PEMBELAJARAN DALAM ERA “NEW NORMAL" DI PONDOK PESANTREN NURUL QARNAIN JEMBER TAHUN 2020. LISAN AL-HAL: Jurnal Pengembangan Pemikiran dan Kebudayaan, 14(2), 361-380.

Hosaini, H. (2019). Behauvioristik Basid Learning Dalam Bingkai Pendidikan Islam Perspektif AlGhazali:(Pembelajaran Berbasis Prilaku Dalam Pandangan Pendidikan Islam). Edukais: Jurnal Pemikiran Keislaman, 3(1), 23-45.

Muslimin, M., \& Hosaini, H. (2019). KONSEP PENDIDIKAN ANAK MENURUT AL-QUR'AN DAN HADITS. Edupedia: Jurnal Studi Pendidikan dan Pedagogi Islam, 4(1), 67-75. 